\title{
Silver Nanoparticles in PEDOT:PSS Layer for Polymer Solar Cell Application
}

\author{
Agnieszka Iwan, Bartosz Boharewicz, Igor Tazbir, \\ Andrzej Sikora, and Beata Zboromirska-Wnukiewicz \\ Division of Electrotechnology and Materials Science, Electrotechnical Institute, M. Sklodowskiej-Curie 55/61 Street, \\ 50-369 Wroclaw, Poland \\ Correspondence should be addressed to Agnieszka Iwan; a.iwan@iel.wroc.pl
}

Received 29 October 2014; Accepted 19 January 2015

Academic Editor: Mohammad Muneer

Copyright (C) 2015 Agnieszka Iwan et al. This is an open access article distributed under the Creative Commons Attribution License, which permits unrestricted use, distribution, and reproduction in any medium, provided the original work is properly cited.

We compare the performance of polymer solar cells based on poly(3-hexylthiophene) (P3HT) and [6,6]-phenyl-C61-butyric acid methyl ester (PCBM) with silver nanoparticles (Ag NPs) incorporated in poly(3,4-ethylenedioxythiophene):poly(styrenesulfonate) (PEDOT:PSS). The structure of constructed solar devices was ITO/PEDOT:PSS:Ag NPs/P3HT:PCBM/Al. Typical polyol chemistry was used to synthesize silver in water solution. Ag nanoparticles were investigated by UV-vis, atomic force microscopy (AFM), and dynamic light scattering (DLS) methods. We investigated influence of amount of silver in a hole transporting layer on the performance of bulk heterojunction polymer solar cells. The value of power conversion efficiency (PCE), equal to $2.16 \%$ under simulated $100 \mathrm{~mW} / \mathrm{cm}^{2}$ AM 1.5G irradiation, was found for device created in air with $60 \mu \mathrm{L}$ of Ag NPs added to $1 \mathrm{~mL}$ of PEDOT:PSS. Along with the increase amount of Ag NPs from 60 to $150 \mu \mathrm{L}$, the PCE decrease was found. Stability of solar cells with Ag was also investigated. The loss in value of PCE after 8 months was found in the range 13-47\% depending on the device architecture. The solar cells were additionally measured with impedance spectroscopy.

\section{Introduction}

Recent development in organic solar cells (OSCs) is addressed to increase value of power conversion efficiency (PCE) by different plasmonic nanoparticles (NPs) introduction [e.g., [1,2]]. This kind of organic solar cells is classified as fourth generation of photovoltaic devices and could include such NPs as carbon nanotubes, graphene, graphene oxide and their chemical modifications, quantum dots, various oxides such as $\mathrm{TiO}_{x}, \mathrm{MoO}_{3}, \mathrm{~V}_{2} \mathrm{O}_{5}$, or $\mathrm{ZnO}$, or different metals (Ag, $\mathrm{Au}, \mathrm{Pt}$ ). NPs could be applied as component of (i) active layer, (ii) hole transporting layer, (iii) electrodes, and (iv) interlayer in OSCs (e.g., [1-6]).

Poly(3,4-ethylenedioxythiophene):poly(styrenesulfonate) (PEDOT:PSS) has high work function, high transparency, and good conductivity and is most popular hole transporting layer (HTL) in polymer solar cells [7]. PEDOT:PSS suffers from the following reasons: (i) aggregates of particles in water solution of PEDOT:PSS, (ii) strong acid character of PSS in PEDOT:PSS, and (iii) hydrophilic character of PEDOT:PSS causing nonhomogeneity of the film morphology and electrical properties along with term stability of polymer devices [8]. To solve these problems various inorganic compounds such as $\mathrm{V}_{2} \mathrm{O}_{5}, \mathrm{WO}_{3}, \mathrm{NiO}, \mathrm{MoO}_{3}$, and organic compounds (poly(styrene sulfonic acid) grafted with polyaniline, polypyrrole-polystyrene sulfonate, or PEDOT:PSS with amphiphilic surfactant Surfynol 104 series, new polymer with carbazole and $\mathrm{PO}_{3}$ moieties, graphene oxide) are proposed instead or together with PEDOT:PSS in polymer solar cells [2, 7-13].

Moreover, various metal nanoparticles (NPs) such as Ag, $\mathrm{Au}$, or mixture of both are investigated in organic solar cells and can enhance the light absorption $[1,2]$. The various NPs are applied in HTL or in organic layer of polymer solar cells for light trapping [14]. It is known that several techniques such as inclusion of periodic nanostructures, diffraction gratings, metallic nanoparticles, or combination of NPs and gratings are proposed [14]. NPs in OSCs can be tested in HTL, active layer or on the layer [e.g., [15-19]]. 

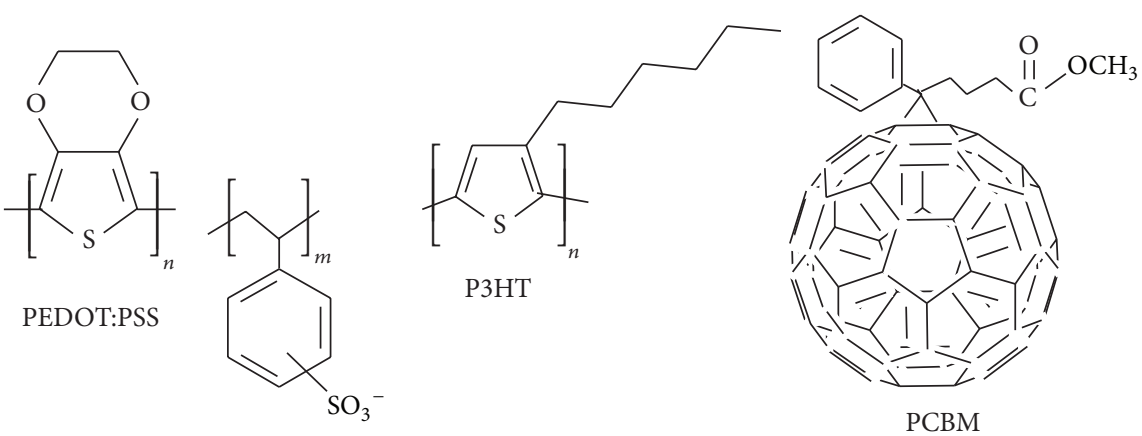

FIgure 1: Chemical structure of PEDOT:PSS, P3HT, and PCBM.

In this work, we presented influence of amount of silver nanoparticles in PEDOT:PSS layer on the performance of BHJ polymer solar cells based on poly(3-hexylthiophene) (P3HT) as a donor and [6,6]-phenyl-C61-butyric acid methyl ester (PCBM) as an acceptor. We show here that, along with the decrease of the Ag amount in hole transporting layer from 150 to $60 \mu \mathrm{L}$, the performance of polymer solar cells increased. As a result, we achieved a high PCE of $2.16 \%$ for constructed BHJ polymer solar cell with $60 \mu \mathrm{L}$ of Ag NPs in $1 \mathrm{~mL}$ PEDOT:PSS.

\section{Materials and Synthesis Procedure}

General Comments. Chloroform, P3HT, PCBM, $\mathrm{AgNO}_{3}$, and 1,5-pentanediol were purchased from Sigma-Aldrich and used as received. ITO and PEDOT:PSS (5-12 cP) were purchased from Ossila company. Surface resistance of ITO was about $20 \mathrm{ohms} / \mathrm{square}$.

2.1. Synthesis of Silver Nanoparticles. Silver nanoparticles (Ag NPs) were obtained by typical polyol chemistry based on synthesis described in [17]. Briefly, silver nitrate $(0.09 \mathrm{~g})$ and poly(vinylpyrrolidone) $(0.09 \mathrm{~g})$ were disolved in water and next 1,5-pentanediol $(12 \mathrm{~mL})$ was added. Solution was mixed at $140^{\circ} \mathrm{C}$ for $1 \mathrm{~h}$. Obtained Ag NPs were collected by means of centrifugation with the addition of acetone, water, and ethanol. Ag NPs in water solution were investigated in polymer solar cells.

2.2. Construction of Polymer Solar Cells. Solar cells were constructed on an indium tin oxide- (ITO) coated glass substrate, with the structure ITO/PEDOT:PSS:Ag NPs/P3HT:PCBM/ $\mathrm{Al}$, in air atmosphere. The ITO coated glass substrate was first cleaned with deionised water and then ultrasonicated in isopropanol for about 20 minutes. PEDOT:PSS:Ag NPs was spin cast (2000 rounds per minute, $25 \mathrm{sec}$. and annealed for 10 minutes at $130^{\circ} \mathrm{C}$ ) from aqueous solution, to form a film on the ITO substrate. We added from 60 to $150 \mu \mathrm{L}$ of Ag NPs dispersed in water to $1 \mathrm{~mL}$ of PEDOT:PSS. A mixture of P3HT:PCBM in chloroform solution with weight ratio 1: 0.7 was then spin cast on top of the PEDOT:PSS layer. An aluminum electrode was deposited by thermal evaporation in vacuum of about $5 \times 10^{-5}$ Torr. Then solar cells were annealed for 30 minutes at $130^{\circ} \mathrm{C}$.
2.3. Characterization. UV-vis spectra in chloroform, water solution and in film were recorded with Jasco V670 spectrophotometer. Size of Ag nanoparticles was determined by dynamic light scattering (DLS) method. The measurements were performed by Zetasizer Analyzer Nano ZS, Malvern Instruments, at temperature of 25,35 , and $45^{\circ} \mathrm{C}$. The basic distribution from the DLS measurement method is the distribution of intensity. The AFM measurements were performed using intermittent contact mode in air and room temperature $\left(25^{\circ} \mathrm{C}, \mathrm{RH}=35 \%\right)$. The Innova instrument from Bruker (former Veeco) was used. Typical probes were utilized to perform the measurements (about $40 \mathrm{~N} / \mathrm{m}$ and $<10 \mathrm{~nm}$ tip radius). Acquired data was analyzed using SPIP software from Image Metrology [20].

Conductivity of PEDOT:PSS with AgNPs layers was measured for ITO/PEDOT:PSS:Ag NPs/Al structure at $25^{\circ} \mathrm{C}$ for 100,200 , and $500 \mathrm{mV}$. The thickness of the PEDOT:PSS: Ag NPs layer was determined by AFM technique by measuring the height of the edge developed using sharp copper blade.

Current density-voltage $(J-V)$ characteristics of the solar cells were measured using Solar Simulator Model SS100AAA with AM 1.5G. For simulation of solar irradiation a xenon lamp with irradiation intensity of $100 \mathrm{~mW} / \mathrm{cm}^{2}$ was used. The area of one photovoltaic pixel was $4.5 \mathrm{~mm}^{2}$. The solar cells were also measured with impedance spectroscopy by Solartron precision LCR meter Model SI1260, in the frequency range of $1 \mathrm{~Hz}$ to $1 \mathrm{MHz}$ with $20 \mathrm{mV}$ test signal under illumination (halogen lamp).

\section{Results and Discussion}

3.1. Characterization of AgNPs, PEDOT:PSS:AgNPs, P3HT, and P3HT:PCBM. Figure 1 presents the chemical structure of P3HT, PCBM, and PEDOT:PSS. Silver nanoparticles were obtained by polyol chemistry [17] and characterized by UVvis, DLS, and AFM study.

The AFM images showed that the size of Ag NPs and the thickness of PEDOT:PSS layer are about 55 and $59 \mathrm{~nm}$, respectively, which indicate that $\mathrm{Ag}$ are imbedded with PEDOT:PSS. The same observation was found in [10] for Ag and Au NPs. The thickness of PEDOT:PSS layer with Ag NPs was approximately $60 \mathrm{~nm}$. Figure 2 shows AFM images of PEDOT:PSS and Ag NPs. 

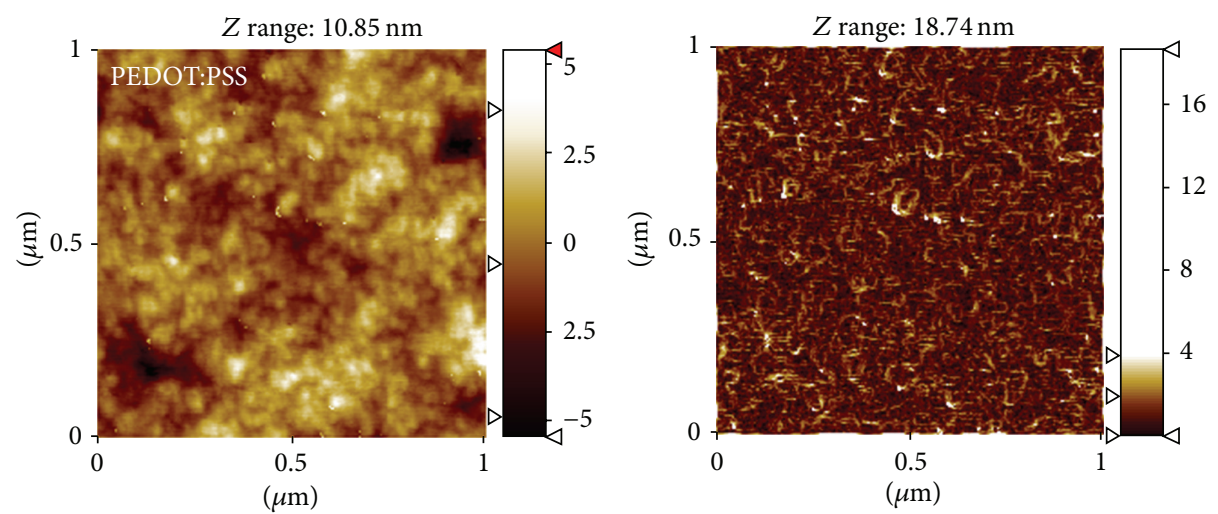

(a)
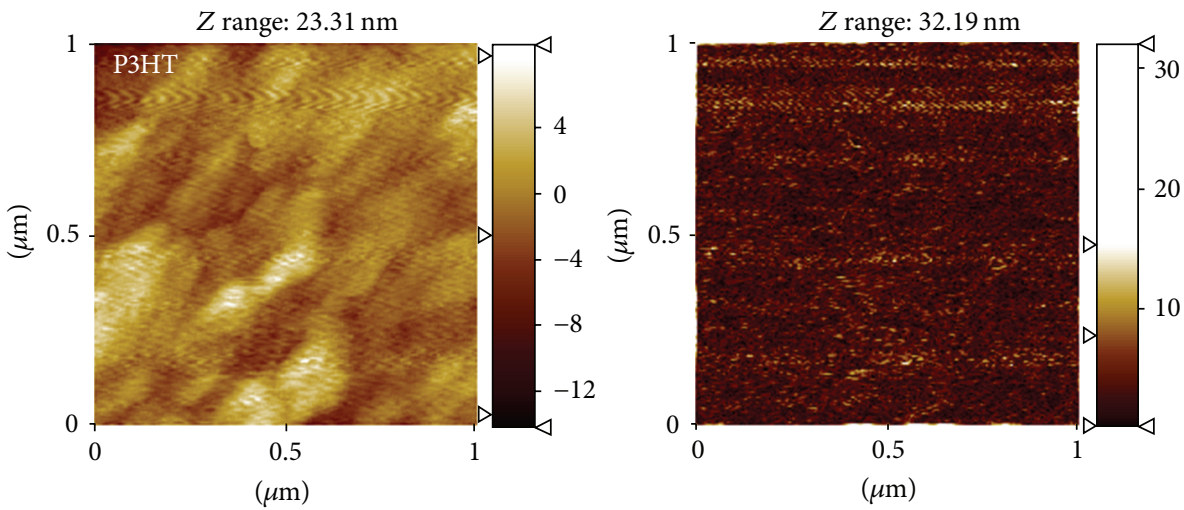

(b)
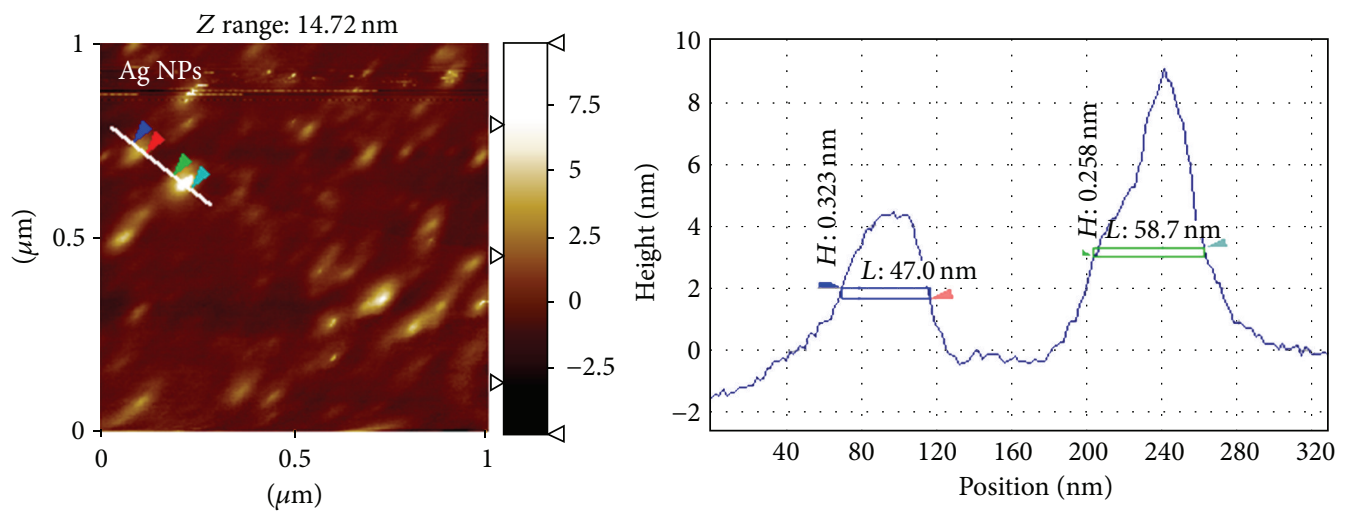

$X(\mathrm{~nm}) Y(\mathrm{~nm})$ M1 $70.470 \quad 2.002$ $\begin{array}{lll}M 2 & 117.45 & 1.679\end{array}$ M2-M1 $46.980-0.3226$ $d y / d x-0.00687 \sim-0.3935^{\circ}$ Mean 1-2: $3.5082 \mathrm{~nm}$ M3 $203.58 \quad 3.003$ $\begin{array}{lll}M 4 & 262.31 & 3.261\end{array}$ M4-M3 $58.725 \quad 0.2577$ $d y / d x \quad 0.00439 \sim 0.2514^{\circ}$ Mean 3-4: $5.8025 \mathrm{~nm}$ Mean dif.: $2.2942 \mathrm{~nm}$ Physical image coord.: $-417.2,-241.1,2.002$

(c)
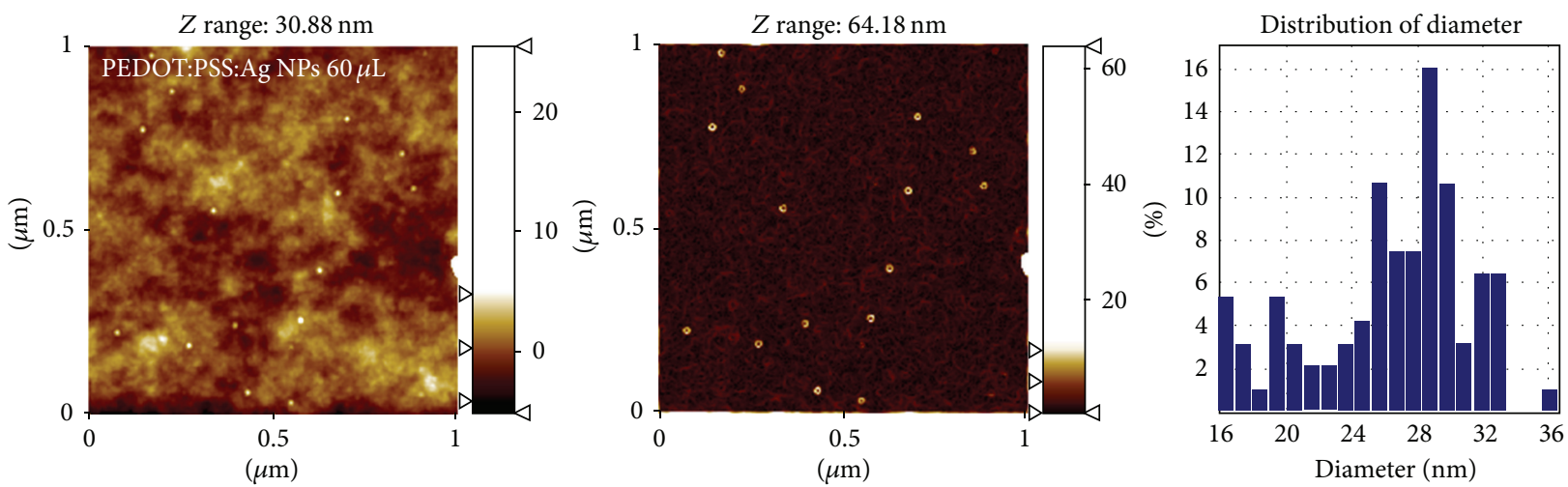

(d)

FIGURE 2: Continued. 

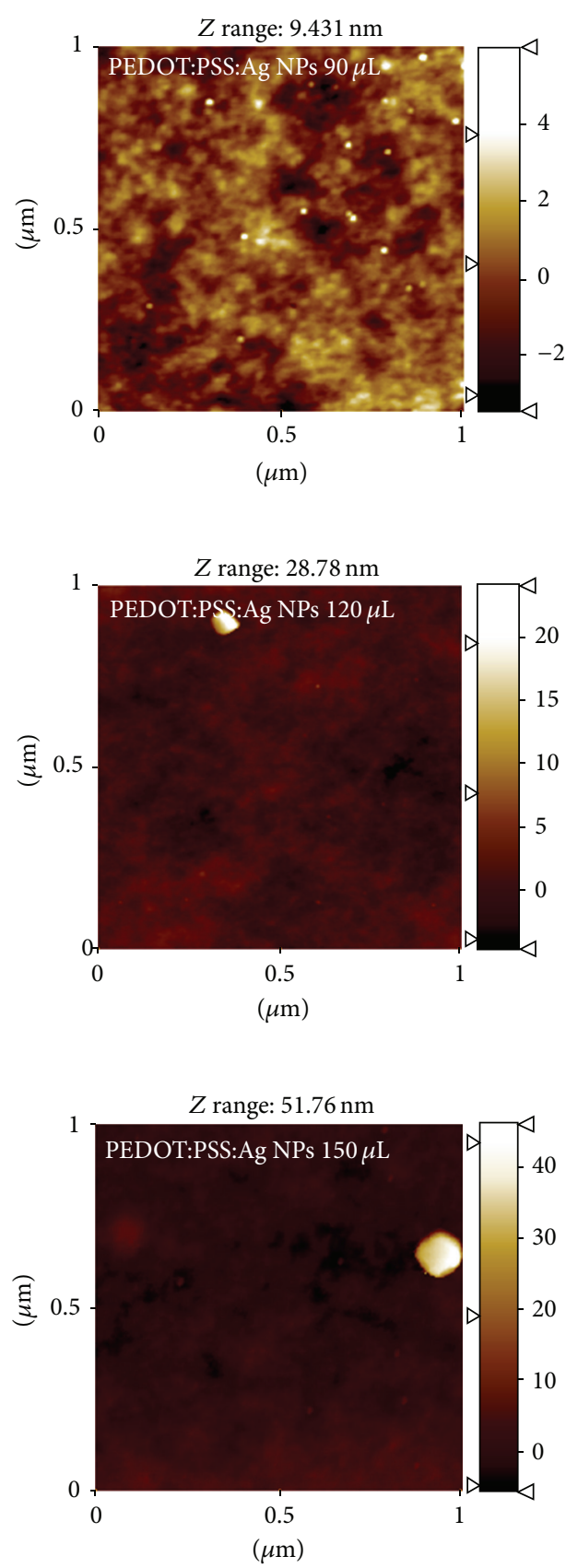

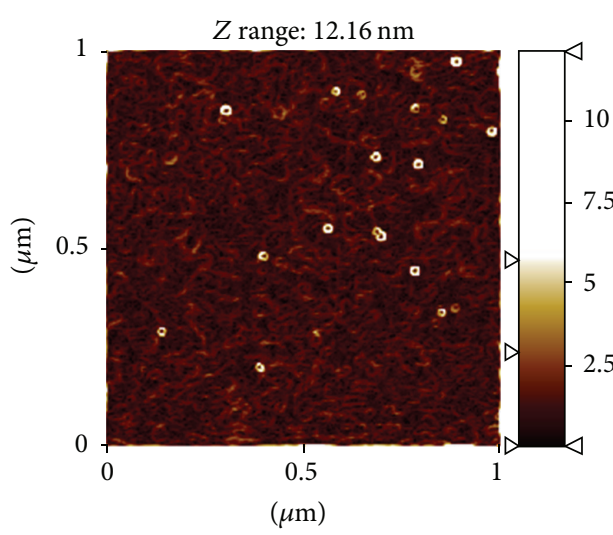

(e)

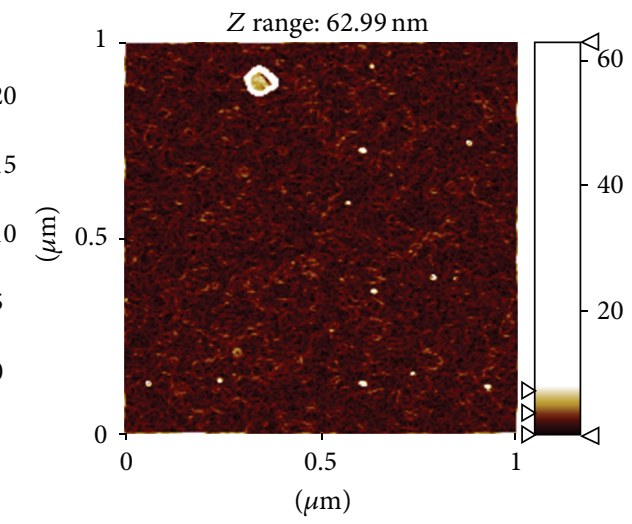

(f)
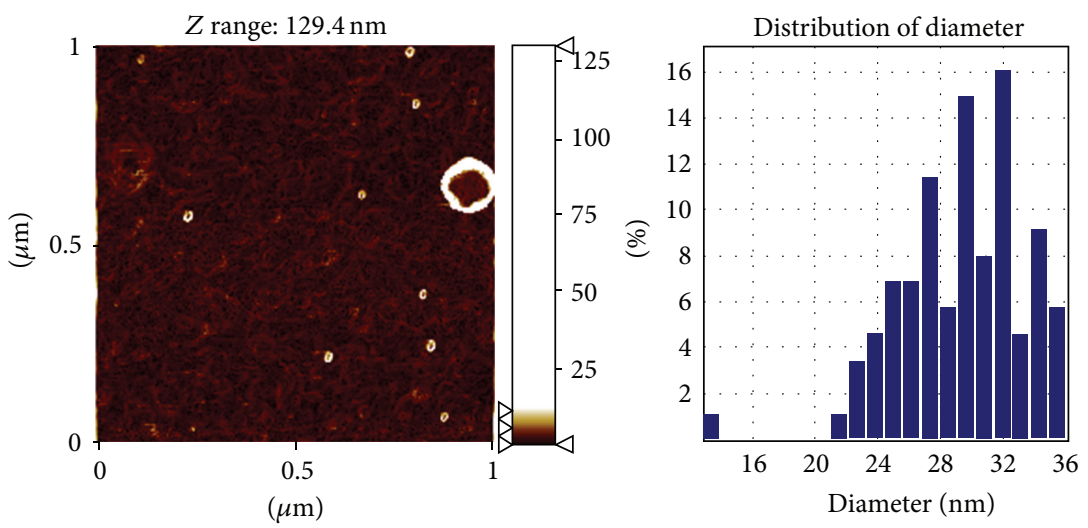

(g)

FIGURE 2: AFM images (topography and Sobel transform) of PEDOT:PSS, P3HT, Ag NPs, and PEDOT:PSS:Ag NPs (60, 90, 120, and 150 $\mu \mathrm{L}$ of silver NPs in $1 \mathrm{~mL}$ of PEDOT:PSS layer) along with particle size distribution calculated by AFM analysis for scan field $3 \times 3 \mu \mathrm{m}$, from top to bottom, respectively.

One can notice the presence of Ag particles on the surface. Sobel transform reveals efficiently even such small objects on large surfaces with complex morphology [12, 21]. It should be noted that, due to immersion of the particles in the compound, only their top parts are exposed and detected by the scanning tip. As a consequence, the histograms present the diameter values of the particles significantly smaller than expected and determined using DLS method. One can however notice a specific distribution of the size, indicating typical depth of the particles immersion, which may be related with specific immersion depth balance due viscosity of the compound. As the distributions differ for each sample, one can argue if it is caused by fine fluctuations of the preparation conditions. Such an approach may allow explaining no correlation between the particles count on the surface and the particles amount for each material.

Typical parameters of topography, such as roughness $\left(R_{a}\right.$, $R_{\mathrm{ms}}$ ), for the investigated surfaces are presented in Table 1. 
TABLE 1: The surface parameters of PEDOT:PSS:Ag NPs layers.

\begin{tabular}{lcc}
\hline Amount of Ag NPs in & \multicolumn{2}{c}{ Surface statistics* } \\
$1 \mathrm{~mL}$ PEDOT:PSS $[\mu \mathrm{L}]$ & $S_{a}[\mathrm{~nm}]$ & $S_{q}[\mathrm{~nm}]$ \\
\hline 0 & 0.98 & 1.27 \\
60 & 0.93 & 1.24 \\
90 & 0.80 & 1.01 \\
120 & 0.84 & 1.05 \\
150 & 2.04 & 4.33 \\
\hline
\end{tabular}

${ }^{*}$ Values calculated for scanning field $1 \mu \mathrm{m} \times 1 \mu \mathrm{m}$.

The root-mean-squared $\left(S_{q}\right)$ roughness of PEDOT:PSS and P3HT layers on glass substrate was about 1.27 and $2.37 \mathrm{~nm}$, respectively. Values of $S_{q}$ for PEDOT:PSS with Ag NPs decrease along with increase in the amount of silver nanoparticles from $1.24 \mathrm{~nm}$ for $60 \mu \mathrm{L}$ of silver to about $1.05 \mathrm{~nm}$ for $120 \mu \mathrm{L}$ of silver NPs. As is shown in Table 1 almost no differences were observed in the values of $S_{q}$ for 90 and $120 \mu \mathrm{L}$ of silver in PEDOT:PSS layer. Probably during the film casting some of the Ag NPs aggregated and formed on the top of the PEDOT:PSS layer randomly distributed Ag clusters. Similar conclusion was presented by Wang et al. [17]. Only in the case of $150 \mu \mathrm{L}$ of silver in PEDOT:PSS layer $S_{q}$ increase in comparison with other samples with and without Ag NPs (see Table 1). This behavior suggested that probably in the case of $150 \mu \mathrm{L}$ of silver NPs the Ag NPs are mainly located on the PEDOT:PSS layer so that the $S_{q}$ roughness increased as is presented in Table 1 . In the cases of $60 \mu \mathrm{L}$ of silver in PEDOT:PSS layer almost the same value of $S_{q}$ was observed and suggested that probably all the Ag NPs are located within the PEDOT:PSS layer. Similar effect was found by Lu et al. [10].

In Figure 3 angular spectra of PEDOT:PSS:Ag NPs for the scanning field $1 \mu \mathrm{m} \times 1 \mu \mathrm{m}$ are presented. The texture direction $\left(S_{\mathrm{td}}\right)$ is defined as the angle of the dominating texture in the image. For images consisting of parallel ridges, the texture direction is parallel to the direction of the ridges. This parameter is only meaningful if there are morphological objects oriented in privileged direction. The texture direction index $\left(S_{\text {tdi }}\right)$ is a measure of how dominant the dominating direction is, and is defined as the average amplitude sum divided by the amplitude sum of the dominating direction.

For all investigated materials the presence of submicron level of organization was observed. Additionally, the $S_{\mathrm{td}}$ and $S_{\text {tdi }}$ factors indicate certain level of ordering of the features, which changes along with the morphological properties during the adding various amount of Ag NPs to $1 \mathrm{~mL}$ of PEDOT:PSS. The increase of the ordering (decrease of $S_{\text {tdi }}$ parameter) is visible along with decrease in the amount of silver in HTL layer. Value of $S_{\text {tdi }}$ was the lowest for PEDOT:PSS with $60 \mu \mathrm{L}$ of Ag NPs (0.432).

Additionally, we investigated size of Ag NPs by DLS method. Average size of silver NPs at $25^{\circ} \mathrm{C}$ was found about $65 \mathrm{~nm}$ (standard deviation $\sim 2.4 \mathrm{~nm}$ ) and had negative zeta potential at $-2.17 \mathrm{mV}$ (see Figure 4 ).

It is known that the Ag NPs can aggregate. To confirm this hypothesis we investigated by DLS method size of Ag NPs at 35 and $45^{\circ} \mathrm{C}$. Average size of $\mathrm{Ag} \mathrm{NPs}$ at 35 and $45^{\circ} \mathrm{C}$ was found to be about 70 and $94 \mathrm{~nm}$, respectively. Moreover,
Ag NPs at 35 and $45^{\circ} \mathrm{C}$ had negative zeta potential at -1.90 and $-0.17 \mathrm{mV}$, respectively. This fact confirmed that the Ag NPs can aggregate.

Figure 5(a) shows UV-vis absorption spectra of synthesized Ag NPs, PEDOT:PSS, and PEDOT:PSS with different amount of Ag NPs. Silver NPs have two maxima of absorbance at 264 and $426 \mathrm{~nm}$. Aqueous solutions of PEDOT:PSS and PEDOT:PSS with different amount of Ag NPs have one main absorption band at $261 \mathrm{~nm}$ and shoulder in the range $300-350 \mathrm{~nm}$ which could be seen in UV-vis spectra. Moreover, broad absorption band was observed at about $900 \mathrm{~nm}$ for PEDOT:PSS and PEDOT:PSS with different amount of Ag NPs (see Figure 5).

In our case silver NPs do not influence the big changes in UV-vis spectra of PEDOT:PSS in aqueous solution. However, influence on the changes in electrical properties of constructed devices is presented below. UV-vis spectra of PEDOT:PSS with and without Ag NPs look similar, however different the UV-vis spectrum of Ag NPs. Similar behavior was presented by Lu et al. [10] and Wang et al. [17]. In [17] authors presented UV-vis spectra of film without and with Ag NPs (40 nm size) in active layer PCDTBT:PC ${ }_{70} \mathrm{BM}$ and did not observe differences in shape and absorbance maxima. In [10] Ag NPs were incorporated to PTB7:PC ${ }_{70}$ BM layer and also no big differences in UV-vis spectra were observed. This part of our work needs more investigations.

Additionally, in Figure 5(b) UV-vis spectra of P3HT and P3HT:PCBM in chloroform solution and in film in the region $350-800 \mathrm{~nm}$ are presented. In chloroform solution both P3HT and P3HT:PCBM exhibited bathochromic shift of the maximum of absorption bands in comparison with their films. P3HT in solution exhibited two absorption bands at 451 and $600 \mathrm{~nm}$, while in the film two bands were found at 548 and $605 \mathrm{~nm}$. UV-vis spectra of P3HT:PCBM exhibited one bond below $350 \mathrm{~nm}$ corresponding to PCBM (at 329 and $335 \mathrm{~nm}$, resp., in solution and in film) and are not showed in Figure 5(b). In the region of 350-800 $\mathrm{nm}$ in the P3HT:PCBM mixture exhibited one maximum band at $454 \mathrm{~nm}$ (in chloroform solution) and at $492 \mathrm{~nm}$ (in film) (see Figure 5).

The conductivity $(\sigma)$ of $\mathrm{P} 3 \mathrm{HT}$ was approximately $6.2 \times$ $10^{-8} \mathrm{~S} / \mathrm{cm}$ at $100 \mathrm{mV}$. Along with increase of voltage from 100 to $500 \mathrm{mV}$ increases in conductivity of the polymer were found. The conductivity at $200 \mathrm{mV}$ was $6.5 \times 10^{-8} \mathrm{~S} / \mathrm{cm}$, while at $500 \mathrm{mV}$ was $1.3 \times 10^{-7} \mathrm{~S} / \mathrm{cm}$.

Moreover, we investigated the influence of Ag NPs on the conductivity of PEDOT:PSS. The conductivity of PEDOT:PSS was approximately $2.0 \times 10^{-7} \mathrm{~S} / \mathrm{cm}$ at $100 \mathrm{mV}$. The conductivity at $200 \mathrm{mV}$ was $2.1 \times 10^{-7} \mathrm{~S} / \mathrm{cm}$, while at $500 \mathrm{mV}$ was $2.4 \times 10^{-7} \mathrm{~S} / \mathrm{cm}$. Silver nanoparticles increase the conductivity value in the range of $29-85 \%$ as is presented in detail in Table 2.

3.2. Photovoltaic Characterization. Polymer solar cells with the glass/ITO/PEDOT:PSS:Ag NPs/P3HT:PCBM/Al architecture were fabricated and measured under AM 1.5G illumination at $100 \mathrm{~mW} / \mathrm{cm}^{2}$. We tested devices without and with $60,90,120$, and $150 \mu \mathrm{L}$ of silver NPs in $1 \mathrm{~mL}$ of PEDOT:PSS layer. Table 3 provides a summary of PV parameters. 

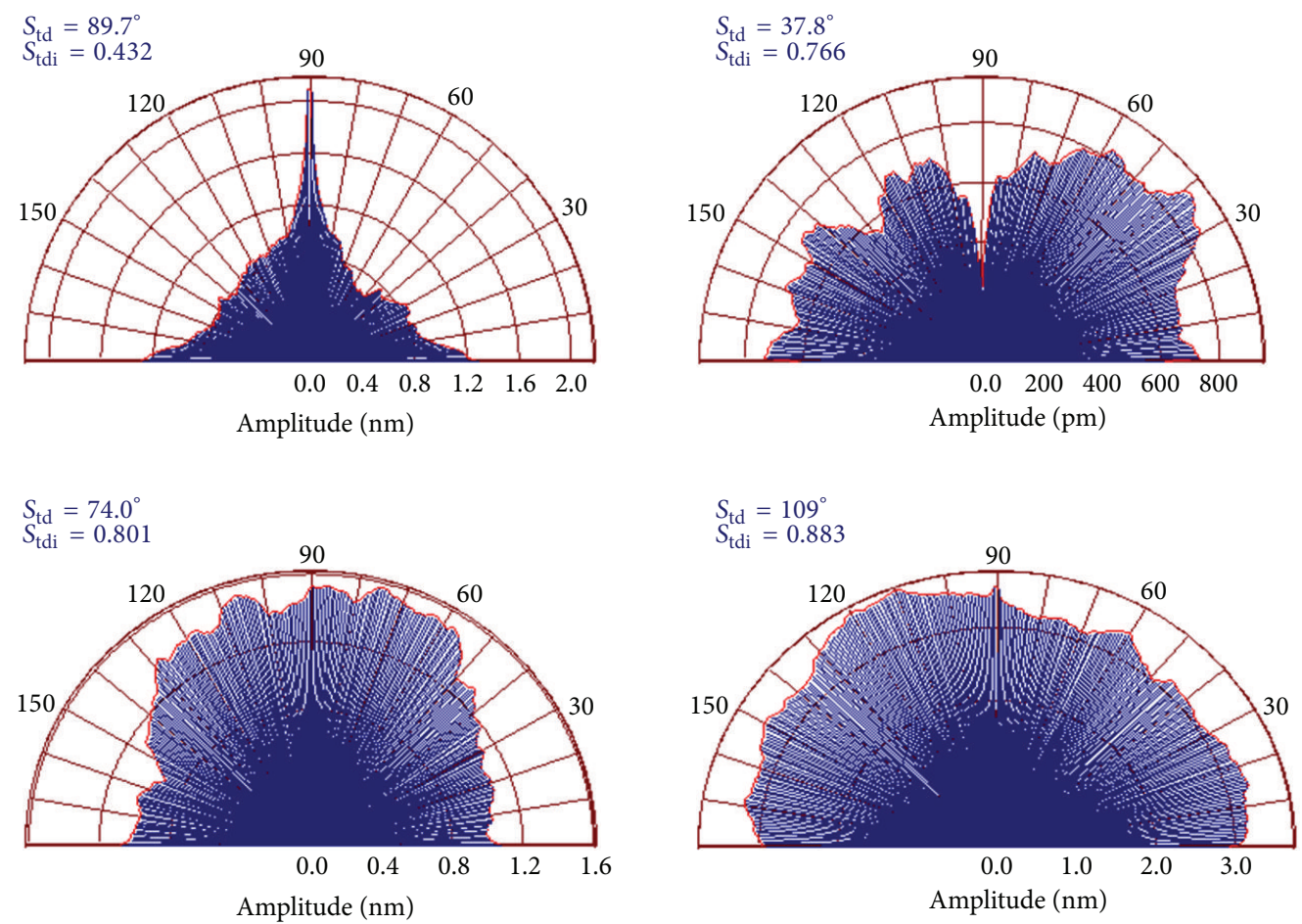

Figure 3: Angular spectra of PEDOT:PSS:Ag NPs with 60, 90, 120, and $150 \mu \mathrm{L}$ of silver NPs from left to right, respectively.

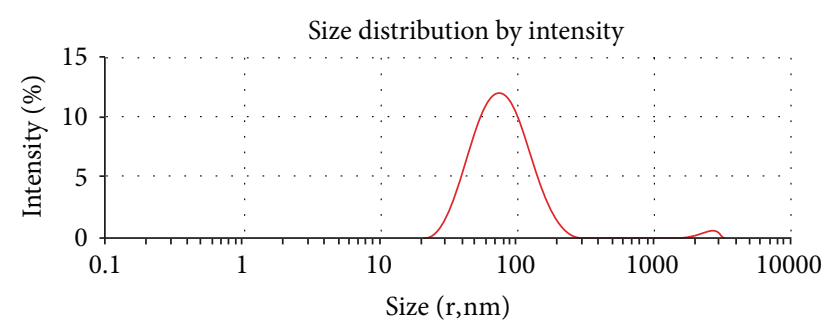

Figure 4: Ag NPs size distribution at $25^{\circ} \mathrm{C}$ detected by DLS.

TABLE 2: Conductivity values of PEDOT:PSS:Ag NPs layers.

\begin{tabular}{lccc}
\hline \multicolumn{4}{c}{$\sigma\left[10^{-7} \mathrm{~S} / \mathrm{cm}\right]$} \\
$\begin{array}{l}\text { Amount of Ag NPs in } \\
1 \mathrm{~mL} \text { PEDOT:PSS }[\mu \mathrm{L}]\end{array}$ & $100 \mathrm{mV}$ & $200 \mathrm{mV}$ & $500 \mathrm{mV}$ \\
\hline 0 & 2.0 & 2.1 & 2.4 \\
60 & 2.7 & 2.8 & 3.9 \\
90 & 2.7 & 2.8 & 3.1 \\
120 & 3.7 & 3.7 & 4.0 \\
150 & 2.8 & 2.9 & 3.3 \\
\hline
\end{tabular}

Along with increase amount of Ag NPs decrease in power conversion value (PCE) was observed. The highest PCE was found for the device with $60 \mu \mathrm{L}$ of silver NPs in $1 \mathrm{~mL}$ of PEDOT:PSS layer. After adding various amounts of Ag NPs into PEDOT:PSS layer open circuit voltage $\left(V_{\mathrm{oc}}\right)$ was the same $(0.60 \mathrm{~V})$, except device with $150 \mu \mathrm{L}$ of silver NPs. Value of short circuit current density $\left(J_{\mathrm{sc}}\right)$ decreases along with increase in the amount of Ag NPs in PEDOT:PSS layer (see Table 3). Fill factor (FF) increased along with decrease in the amount of Ag NPs. As a result, PCE is enhanced from $1.80 \%$ for $150 \mu \mathrm{L}$ of silver to $2.16 \%$ for $60 \mu \mathrm{L}$ of Ag NPs. As we can see the maximum PCE value was observed for the device with $60 \mu \mathrm{L}$ of silver NPs in $1 \mathrm{~mL}$ of PEDOT:PSS layer. Our preliminary study showed that for device with $30 \mu \mathrm{L}$ of Ag NPs in $1 \mathrm{~mL}$ of PEDOT:PSS layer the value of PCE was lowest $(1.24 \%)$ compared to that for the device with $60 \mu \mathrm{L}$ of Ag NPs (2.16\%). Moreover, our study showed that for the device without Ag NPs the PCE value was found at 2.77\% (see Table 3). It shows that the addition of Ag NPs to PEDOT:PSS decreases the PCE value of devices.

To check if Ag NPs influence the lifetime of constructed polymer solar cells after 8 months all devices (encapsulated devices were kept in laboratory in air atmosphere) were again tested. The lowest loss in PCE was found for device with $90 \mu \mathrm{L}$ of silver NPs in $1 \mathrm{~mL}$ of PEDOT:PSS layer. It is about $13 \%$ and refers to the PCE value of new device (2.05\%) (see Table 3). For the device without Ag NPs measurement after eight months 30\% loss in value of PCE was found (see Table 3).

The $J-V$ (current density-voltage) characteristics of $\mathrm{BHJ}$ solar cells with Ag NPs constructed in air atmosphere are presented in Figure 6.

Electrochemical impedance spectroscopy (EIS) was applied to measure constructed polymer solar cells with Ag NPs under illumination. Nyquist plots for devices are presented in Figure 7 along with equivalent circuits of ITO/PEDOT:PSS:Ag NPs/P3HT:PCBM/Al devices. EIS experiments were analyzed based on the published papers $[22,23]$. 

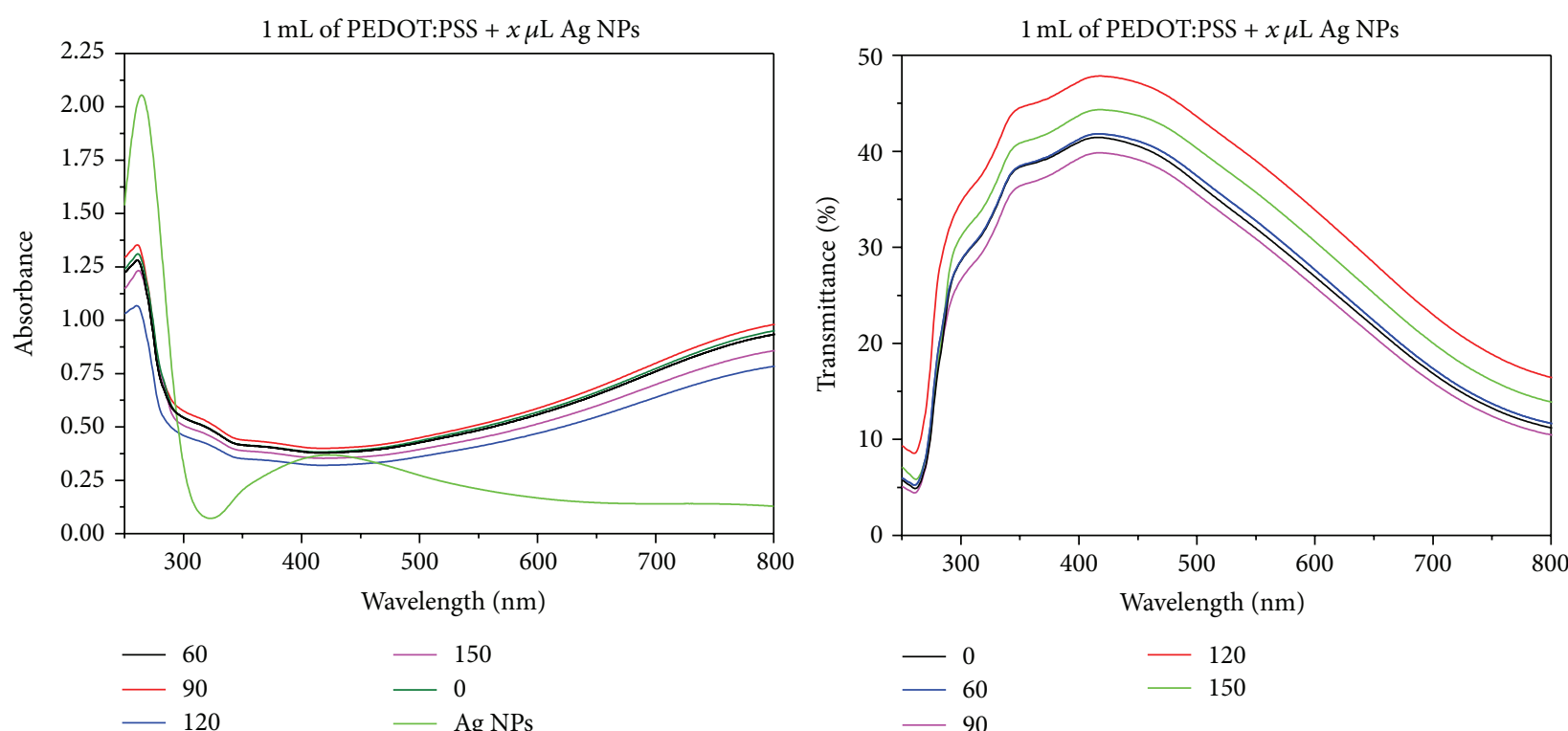

(a)

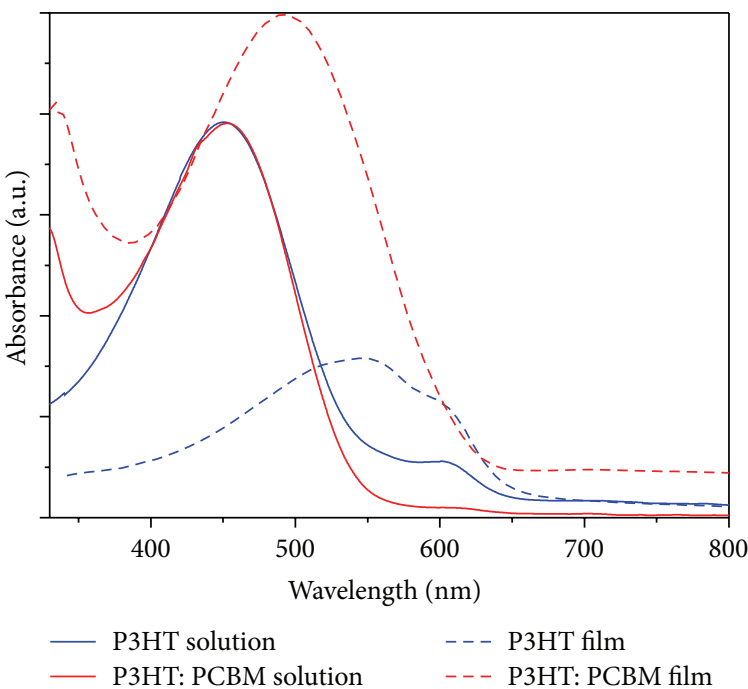

(b)

FIgURE 5: UV-vis spectra of (a) Ag NPs, PEDOT:PSS, and PEDOT:PSS:Ag NPs aqueous solution and (b) P3HT, P3HT:PCBM in film and in chloroform solution.

TABLE 3: Optimized PV performance for BHJ solar cells with Ag NPs under AM 1.5 G-simulated solar illumination $\left(100 \mathrm{~mW} / \mathrm{cm}^{2}\right)$.

\begin{tabular}{|c|c|c|c|c|c|c|}
\hline $\begin{array}{l}\text { Amount of Ag NPs in } \\
1 \text { mL PEDOT:PSS }[\mu \mathrm{L}]\end{array}$ & $J_{\mathrm{sc}}\left[\mathrm{mA} / \mathrm{cm}^{2}\right]$ & $V_{\text {oc }}[\mathrm{V}]$ & $\mathrm{FF}[-]$ & $\mathrm{PCE}_{\mathrm{av} .}[\%]$ & $P_{\max }[\mu \mathrm{W}]$ & $\begin{array}{c}\text { PCE }_{\max } \text { after } 8 \\
\text { months [\%] (lost, \%) }\end{array}$ \\
\hline \multicolumn{7}{|c|}{ ITO/PEDOT:PSS:Ag NPs/P3HT:PCBM/Al } \\
\hline 0 & $8.58( \pm 0.20)$ & $0.598( \pm 0.001)$ & $0.57( \pm 0.02)$ & $2.77( \pm 0.11)$ & 137 & $1.93(30 \%)$ \\
\hline 60 & $7.36( \pm 0.13)$ & $0.604( \pm 0.002)$ & $0.49( \pm 0.05)$ & $2.16( \pm 0.24)$ & 109 & $1.56(28 \%)$ \\
\hline 90 & $7.36( \pm 0.09)$ & $0.607( \pm 0.002)$ & $0.46( \pm 0.03)$ & $2.05( \pm 0.17)$ & 100 & $1.79(13 \%)$ \\
\hline 120 & $7.26( \pm 0.24)$ & $0.604( \pm 0.002)$ & $0.46( \pm 0.08)$ & $2.00( \pm 0.42)$ & 110 & $1.07(47 \%)$ \\
\hline 150 & $6.81( \pm 0.03)$ & $0.557( \pm 0.003)$ & $0.47( \pm 0.01)$ & $1.80( \pm 0.02)$ & 82 & $1.50(17 \%)$ \\
\hline
\end{tabular}

$V_{\mathrm{oc}}$ : open circuit voltage, $J_{\mathrm{sc}}$ : short circuit current density, FF: fill factor, PCE: power conversion efficiency, and $P_{\max }$ : the maximum power of the pixel with $\mathrm{PCE}_{\max }$. 
TABLE 4: The equivalent circuit parameters for ITO/PEDOT:PSS:Ag NPs/P3HT:PCBM/Al obtained from the fitting along with the mean relaxation times received from the parameters of fitting under illumination (halogen lamp).

\begin{tabular}{lccccccccccc}
\hline $\begin{array}{l}\text { Amount of Ag } \\
\text { NPs }[\mu \mathrm{L}]\end{array}$ & $\begin{array}{c}\chi^{2} \\
{\left[\times 10^{-6}\right]}\end{array}$ & $\begin{array}{c}R_{S} \\
{[\Omega]}\end{array}$ & $\begin{array}{c}R_{1} \\
{[\Omega]}\end{array}$ & $\begin{array}{c}Q_{1}-T \\
{\left[\mathrm{~s}^{\mathrm{P}} \Omega^{-1}\right]} \\
{\left[\times 10^{-6}\right]}\end{array}$ & $\begin{array}{c}Q_{1}-P \\
{[-]}\end{array}$ & $\begin{array}{c}R_{2} \\
{[\Omega]}\end{array}$ & $\begin{array}{c}Q_{2}-T \\
{\left[\mathrm{~s}^{\mathrm{p}} \Omega^{-1}\right]} \\
{\left[\times 10^{-6}\right]}\end{array}$ & $\begin{array}{c}Q_{2}-P \\
{[-]}\end{array}$ & $\begin{array}{c}C_{G} \\
{[\mathrm{nF}]}\end{array}$ & $\begin{array}{c}\tau_{1} \\
{[\mu \mathrm{s}]}\end{array}$ & $\begin{array}{c}\tau_{2} \\
{[\mu \mathrm{s}]}\end{array}$ \\
\hline 60 & 765 & 3.71 & 291 & 239.15 & 0.302 & 1790 & 0.140 & 0.914 & 15.84 & 147.0 & 114.9 \\
90 & 3118 & 3.65 & 141.2 & 102.53 & 0.368 & 1437 & 0.193 & 0.902 & 15.04 & 10.04 & 113.9 \\
120 & 616 & 4.13 & 105.9 & 172.02 & 0.312 & 1076 & 0.134 & 0.945 & 15.09 & 2.658 & 86.17 \\
150 & 1111 & 3.70 & 163.2 & 139.15 & 0.362 & 875.5 & 0.319 & 0.845 & 16.33 & 28.78 & 62.25 \\
\hline
\end{tabular}

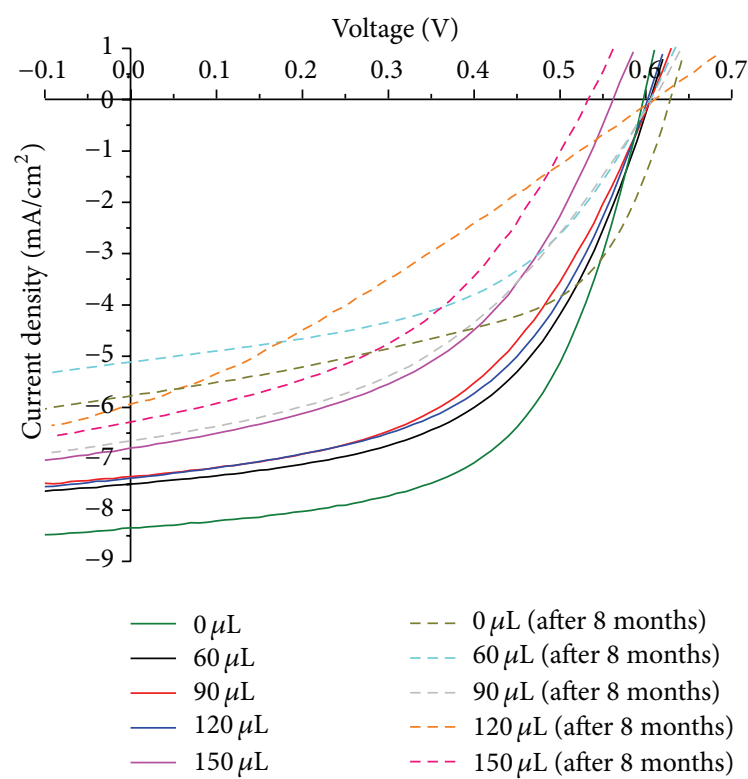

FIGURE 6: Current density-voltage characteristics of all investigated devices with Ag NPs ( $J$ - $V$ measurement immediately after construction and after 8 months).

All studied devices exhibited semicircles in Nyquist plots. Moreover, noticeable drop in values of the real part $\left(Z^{\prime}\right)$ and the imaginary part $\left(Z^{\prime \prime}\right)$ of the complex impedance along with increase in the amount of Ag NPs could be seen as a result of decreasing the diameter of the semicircles (see Figure 7). The diameter of the semicircle for the BHJ solar cells with $60 \mu \mathrm{L}$ of silver NPs in $1 \mathrm{~mL}$ of PEDOT:PSS layer is the largest and also value of PCE of this device is the highest in comparison with the devices with 90,120 , and $150 \mu \mathrm{L}$ of silver NPs in $1 \mathrm{~mL}$ of PEDOT:PSS layer as presented in Table 3. Moreover, the device with $150 \mu \mathrm{L}$ of silver NPs in $1 \mathrm{~mL}$ of PEDOT:PSS layer exhibited the smallest diameter of the semicircle and also the lowest value of PCE (1.80\%), which indicates also the lowest impedance. Fitting parameters of the equivalent circuit are presented in Table 4.

Also, along with the increase of the Ag NPs amount, the decrease of resistance values $\left(R_{1}\right.$ and $\left.R_{2}\right)$ of the devices was found (see Table 4). For the device with $60 \mu \mathrm{L}$ of silver NPs in $1 \mathrm{~mL}$ of PEDOT:PSS layer values of $R_{1}$ and $R_{2}$ and $Q_{1}-T$ were higher in comparison to the other devices.

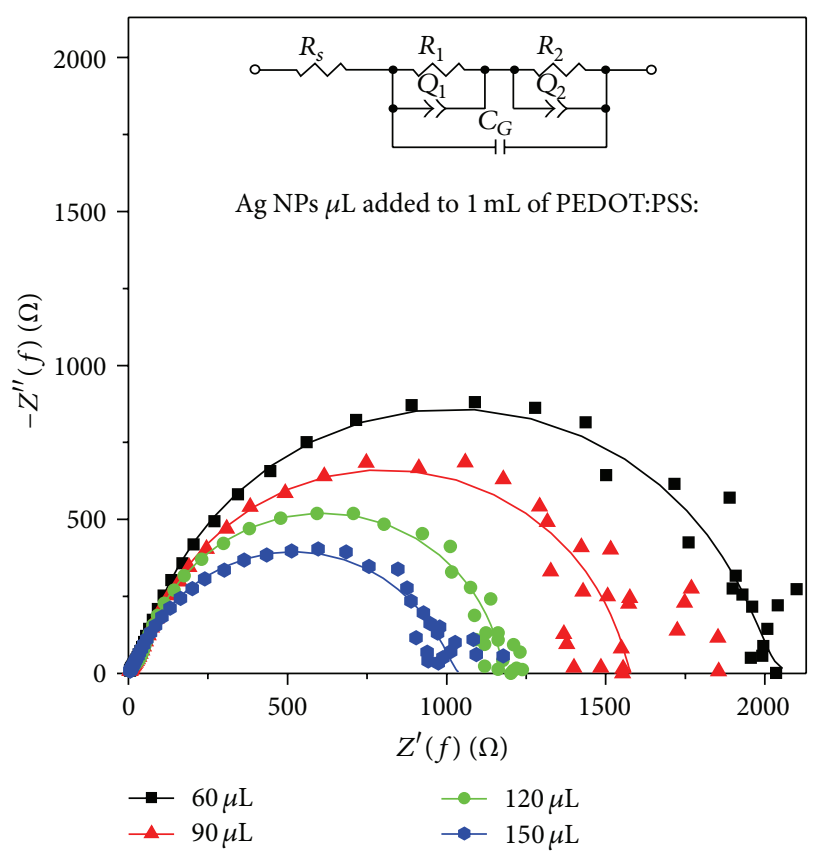

FIGURE 7: Impedance spectra of ITO/PEDOT:PSS:Ag NPs/P3HT: $\mathrm{PCBM} / \mathrm{Al}$ device with $60,90,120$, and $150 \mu \mathrm{L}$ of silver NPs in $1 \mathrm{~mL}$ of PEDOT:PSS layer under illumination devices along with fit results and equivalent circuit of devices. $R_{S}$ represents the series resistance, $C_{G}$ is capacitance between anode and cathode, $R$ is resistance, and $Q=1 /\left(\mathrm{T} \cdot(j \cdot \omega)^{p}\right)$ is constant phase element of investigated layer, where $T$ and $|p| \leq 1$ are parameters. When $0<p<1$ then the parameters correspond to some distribution of charge transport processes rather than to a single one.

The mean relaxation times $\tau_{m}=(\mathrm{RT})^{1 / p}$, where $T: Q-T$ and $p: Q-P(Q$ is constant phase element of the investigated layer, $m=1,2$, and corresponds to the relaxation time of processes that occur within the active layer and at the interface, resp.) were calculated (see Table 4). The highest relaxation time was found for device with $60 \mu \mathrm{L}$ of silver NPs in $1 \mathrm{~mL}$ of PEDOT:PSS layer.

\section{Conclusions}

To conclude, we have demonstrated the influence amount of silver nanoparticles in hole transporting layer on the performance of polymer solar cell based on P3HT:PCBM. Ag NPs were synthesized by polyol chemistry with $60 \mathrm{~nm}$ 
nanoparticles. For device created in air with $60 \mu \mathrm{L}$ of Ag NPs added to $1 \mathrm{~mL}$ of PEDOT:PSS the highest value of PCE, equal to $2.16 \%$, was found. After 8 months device with $60 \mu \mathrm{L}$ of Ag NPs in PEDOT:PSS exhibited 28\% loss in PCE compared with "new" device.

\section{Conflict of Interests}

The authors declare that there is no conflict of interests regarding the publication of this paper.

\section{Acknowledgments}

Agnieszka Iwan expresses her gratitude to the National Centre for Research and Development for a supplementary financial support under the 2012-2015 Project no. PBS1/A5/27/2012. Authors thank Mr. K. Parafiniuk for Ag NPs synthesis.

\section{References}

[1] K. D. G. I. Jayawardena, L. J. Rozanski, C. A. Mills, M. J. Beliatis, N. A. Nismy, and S. R. P. Silva, "Inorganics-in-Organics': recent developments and outlook for $4 \mathrm{G}$ polymer solar cells," Nanoscale, vol. 5, no. 18, pp. 8411-8427, 2013.

[2] M. Notarianni, K. Vernon, A. Chou, M. Aljada, J. Liu, and N. Motta, "Plasmonic effect of gold nanoparticles in organic solar cells," Solar Energy, 2013.

[3] R. Pacios, R. Marcilla, C. Pozo-Gonzalo et al., "Combined electrochromic and plasmonic optical responses in conducting polymer/metal nanoparticle films," Journal of Nanoscience and Nanotechnology, vol. 7, no. 8, pp. 2938-2941, 2007.

[4] N. T. N. Truong, T. P. N. Nguyen, and C. Park, "Structural and optoelectronic properties of CdSe tetrapod nanocrystals for bulk heterojunction solar cell applications," International Journal of Photoenergy, vol. 2013, Article ID 146582, 7 pages, 2013.

[5] Y. Liu, F. Zhang, and J. Wang, "Organic photovoltaic cells based on $\mathrm{PbPc}$ nanocolumns prepared by glancing angle deposition," International Journal of Photoenergy, vol. 2013, Article ID 346818, 6 pages, 2013.

[6] M. S. P. Sarah, F. S. S. Zahid, and M. Rusop, "Investigation on I-V for different heating temperatures of nanocomposited MEH-PPV:CNTs organic solar cells," International Journal of Photoenergy, vol. 2012, Article ID 872324, 6 pages, 2012.

[7] S. W. Heo, K. H. Baek, T. H. Lee, J. Y. Lee, and D. K. Moon, "Enhanced performance in inverted polymer solar cells via solution process: morphology controlling of PEDOT:PSS as anode buffer layer by adding surfactants," Organic Electronics: Physics, Materials, Applications, vol. 14, no. 6, pp. 1629-1635, 2013.

[8] J. W. Jung, J. U. Lee, and W. H. Jo, "High-efficiency polymer solar cells with water-soluble and self-doped conducting polyaniline graft copolymer as hole transport layer," Journal of Physical Chemistry C, vol. 114, no. 1, pp. 633-637, 2010.

[9] E. Andreoli, K.-S. Liao, A. Haldar, N. J. Alley, and S. A. Curran, "PPy:PSS as alternative to PEDOT:PSS in organic photovoltaics," Synthetic Metals, vol. 185-186, pp. 71-78, 2013.

[10] L. Lu, Z. Luo, T. Xu, and L. Yu, "Cooperative plasmonic effect of $\mathrm{Ag}$ and Au nanoparticles on enhancing performance of polymer solar cells," Nano Letters, vol. 13, no. 1, pp. 59-64, 2013.
[11] J. Sun, Y. Zhu, X. Xu et al., "High efficiency and high Voc inverted polymer solar cells based on a low-lying HOMO polycarbazole donor and a hydrophilic polycarbazole interlayer on ITO cathode," Journal of Physical Chemistry C, vol. 116, no. 27, pp. 14188-14198, 2012.

[12] A. Chuchmała, M. Palewicz, A. Sikora, and A. Iwan, "Influence of graphene oxide interlayer on PCE value of polymer solar cells," Synthetic Metals, vol. 169, no. 1, pp. 33-40, 2013.

[13] A. Iwan and A. Chuchmała, "Perspectives of applied graphene: polymer solar cells," Progress in Polymer Science, vol. 37, no. 12, pp. 1805-1828, 2012.

[14] A. Kubacka, M. Fernández-García, and G. Colón, "Advanced nanoarchitectures for solar photocatalytic applications," Chemical Reviews, vol. 112, no. 3, pp. 1555-1614, 2012.

[15] N. Kalfagiannis, P. G. Karagiannidis, C. Pitsalidis et al., "Plasmonic silver nanoparticles for improved organic solar cells," Solar Energy Materials \& Solar Cells, vol. 104, pp. 165-174, 2012.

[16] X. Li, W. C. H. Choy, L. Huo et al., "Dual plasmonic nanostructures for high performance inverted organic solar cells," Advanced Materials, vol. 24, no. 22, pp. 3046-3052, 2012.

[17] D. H. Wang, K. H. Park, J. H. Seo et al., "Enhanced power conversion efficiency in PCDTBT/PC ${ }_{70} \mathrm{BM}$ bulk heterojunction photovoltaic devices with embedded silver nanoparticle clusters," Advanced Energy Materials, vol. 1, no. 5, pp. 766-770, 2011.

[18] R. S. Kim, J. Zhu, J. H. Park et al., "E-beam deposited Agnanoparticles plasmonic organic solar cell and its absorption enhancement analysis using FDTD-based cylindrical nanoparticle optical model," Optics Express, vol. 20, no. 12, pp. 1264912657, 2012.

[19] A. Iwan, B. Boharewicz, A. Hreniak, I. Tazbir, and J. Chmielowiec, "Polymer solar cells with a $\mathrm{TiO}_{2}: \mathrm{Ag}$ layer," Journal of Modern Optics, Special Issue Organic Photovoltaics, vol. 61, pp. 1767-1772, 2014.

[20] http://www.imagemet.com/.

[21] A. Iwan, D. Pociecha, A. Sikora, H. Janeczek, and M. Wegrzyn, "Characterisation and mesomorphic behaviour of new aliphatic-aromatic azomethines containing ester groups," Liquid Crystals, vol. 37, no. 12, pp. 1479-1492, 2010.

[22] G. Garcia-Belmonte, A. Munar, E. M. Barea, J. Bisquert, I. Ugarte, and R. Pacios, "Charge carrier mobility and lifetime of organic bulk heterojunctions analyzed by impedance spectroscopy," Organic Electronics, vol. 9, no. 5, pp. 847-851, 2008.

[23] B. J. Leever, C. A. Bailey, T. J. Marks, M. C. Hersam, and M. F. Durstock, "In situ characterization of lifetime and morphology in operating bulk heterojunction organic photovoltaic devices by impedance spectroscopy," Advanced Energy Materials, vol. 2, no. 1, pp. 120-128, 2012. 

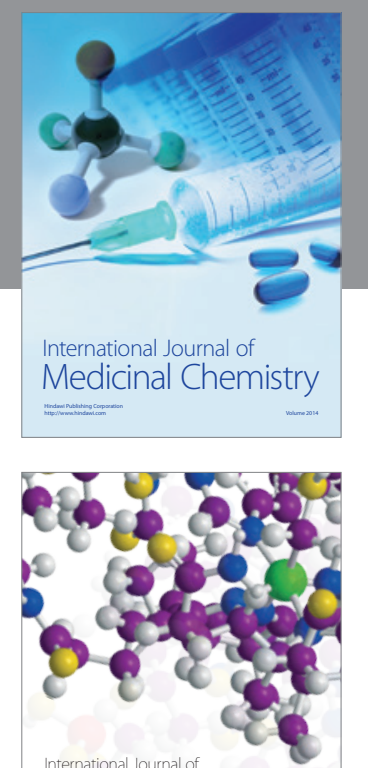

\section{Carbohydrate} Chemistry

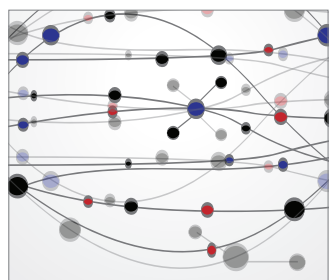

The Scientific World Journal
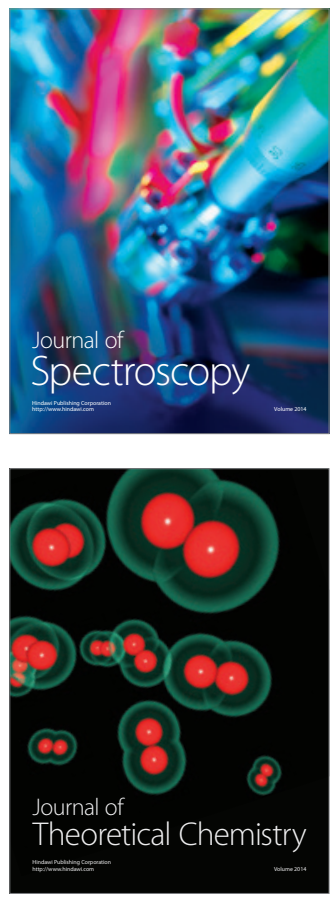
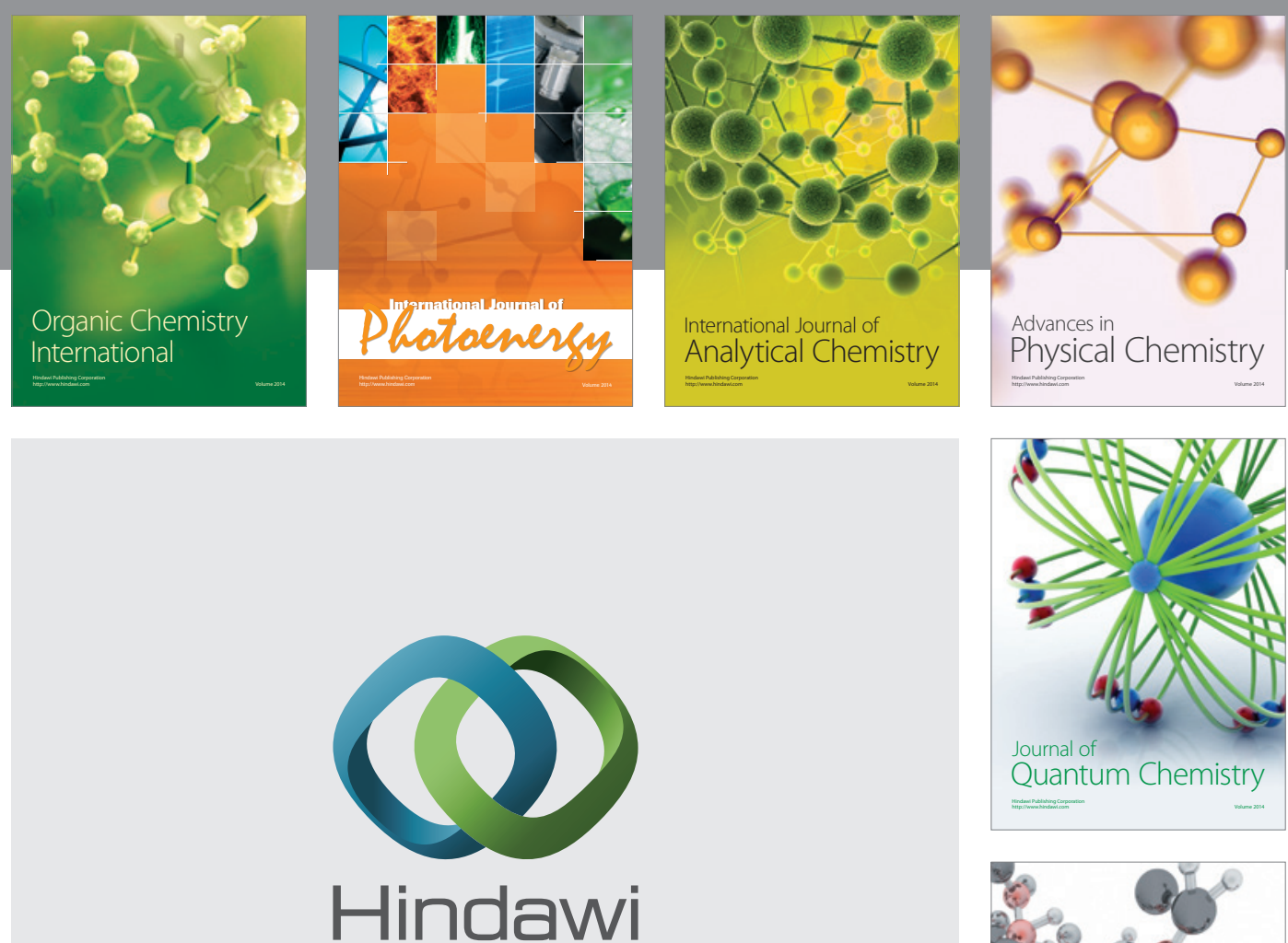

Submit your manuscripts at

http://www.hindawi.com

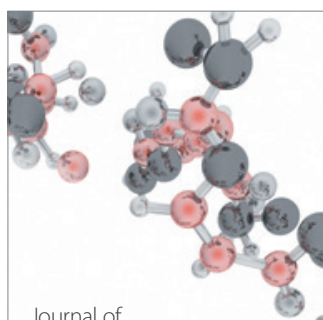

Analytical Methods

in Chemistry

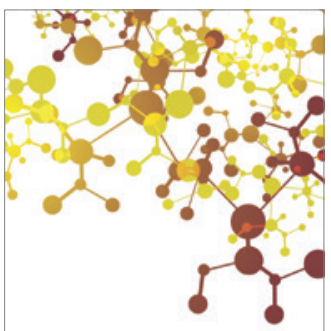

Journal of

Applied Chemistry

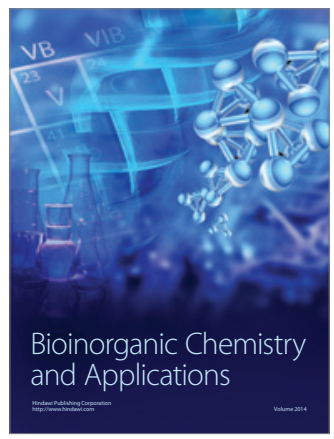

Inorganic Chemistry
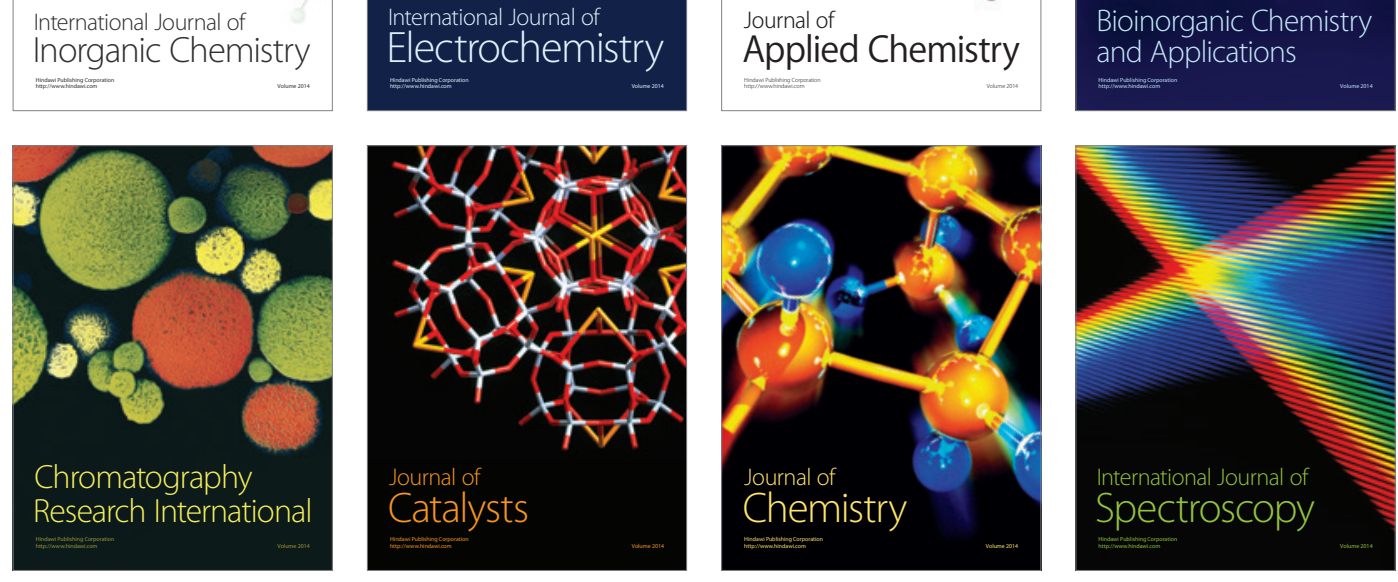